\title{
THE PATHOPHYSIOLOGY OF ENDOTHELIAL FUNCTION IN PREGNANCY AND THE USEFULNESS OF ENDOTHELIAL MARKERS
}

\author{
Ludek Slavik ${ }^{a *}$, Jana Prochazkovaa ${ }^{a}$, Martin Prochazka ${ }^{b}$, Ondrej Simetkac, \\ Antonin Hlusi ${ }^{\mathrm{a}}$, Jana Ulehlova ${ }^{\mathrm{a}}$
}

\author{
a Department of Hemato-oncology, University Hospital Olomouc, Czech Republic \\ ${ }^{b}$ Department of Obsterics and Gynecology, University Hospital Olomouc \\ c Department of Obsterics and Gynecology, University Hospital Ostrava \\ E-mail:ludek.slavik@fnol.cz
}

Received: January 12, 2011; Accepted with revision: April 29, 2011; Available online: May 23, 2011

Key words: Endothelium/Matrix metalloproteinases/Endothelial dysfunction/Coagulation activation markers/Pregnancy complications

Aim. The aim of this study was to assess coagulation markers of endothelial damage and examine new markers of endothelial activation such as matrix metalloproteinases (MMPs) in a group of healthy pregnant women. Matrix metalloproteinase (MMP)-2, in particular, plays a major role in the degradation of the extracellular matrix confirming its essential function in both the survival (angiogenesis) and death of endothelial cells.

Detection of specific coagulation factors, mainly released from the vascular endothelium such as vWF, sTM (soluble thrombomodulin) and ePCR (endothelial protein $\mathrm{C}$ receptor) and factors dependent on endothelial activation such as t-PA and PAI-1, could provide information on possible endothelial dysfunction and help differentiate pregnant patients with an altered thrombotic state.

Methods. Healthy pregnant women underwent complete assessment for endothelial damage (as vWF, vWF activity, sTM, ePCR, EMP, MMP-2, MMP-9 and TIMP-2) using the ELISA and other methods.

Results and Conclusions. The results show that endothelial activation during pregnancy is different from that in other pathological conditions involving endothelial damage and typically characterized by higher levels of both coagulation endothelial markers and MMPs. In pregnancy, changes in extracellular matrix composition and matrix metalloproteinase activity also occur and promote vascular remodeling but, only in the uterus. Predisposing risk factors for epithelial dysfunction, and vascular mediators associated with vascular remodeling must be assessed from concentrations in whole blood. The levels of MMPs are not increased in the circulation and the local situation in the uterus cannot be monitored this way.

However, MMP-2 processes and modulates the functions of many other vasoactive and pro-inflammatory molecules including adrenomedullin, big endothelin-1, calcitonin gene-related peptide, CCL7/MCP-3, CXCL12/SDF-1, galectin-3, IGFBP-3, IL-1 Beta, S100A8, and S100A9. These molecules represent new potential molecular markers of endothelial damage during pregnancy.

\section{INTRODUCTION}

The healthy endothelium secretes and expresses a number of substances that help to maintain vascular wall structure and vascular homeostasis. Endothelial cells modulate their properties to restore vascular homeostasis in response to various aggressive stimuli ${ }^{1}$. Under some pathological conditions however, such as atherosclerosis, endothelial function is chronically disturbed. Advances in recent years have improved our understanding of the pathophysiology of atherosclerosis which is now known to be a dynamic and progressive process proceeding from endothelial dysfunction and inflammation of the vascular wall. The progression of the atherosclerosis and its prognosis, along with the efficacy of therapeutic modalities, can be assessed by measuring the circulating levels of various biomarkers expressed/released by the endothelium. The endothelium in pregnancy on the other hand is less well understood ${ }^{2}$. The purpose of this paper is to reconsider the importance of markers of endothelial function under physiological conditions in normal and pathological pregnancies, and to analyze markers of endothelial function with clinical applicability.

Hypertension and preeclampsia in pregnancy are multisystemic conditions characterized by hypertension, proteinuria and generalized systemic vasoconstriction. Preeclampsia is associated with insufficient trophoblast invasion into maternal spiral arteries. These changes lead to insufficient fetoplacental blood flow. Ischemia of the fetoplacental unit causes the release of specific factors into maternal vessels and subsequent activation of the endothelium and, vasoconstriction. While these factors have not been completely identified so far, it has been found that in the manifest phase of preeclampsia, there is a significantly higher level of markers connected with endothelial damage. 
In this study, we compared coagulation markers of endothelial damage and new markers of endothelial activation such as matrix metalloproteinases. Matrix metalloproteinase (MMP)-2 in particular, plays a major role in the degradation of the extracellular matrix and this underlies the essential function of this enzyme in both the survival (angiogenesis) and death of endothelial cells. Endothelial cells however cannot be detected in blood samples, owing to their very low concentration. To detect the activation mechanism of MMP, analysis of endothelial microparticles (EMPs) is used. The precise mechanisms leading to in vivo microparticle generation by endothelial cells remain unclear. In vitro, a variety of prolonged stimuli have been shown to induce EMP vesiculation from cultured endothelial cells. Combes et al. ${ }^{3}$ first described the generation of EMPs from human umbilical endothelial cells stimulated by tumor necrosis factor- $\alpha$. However, EMP release can be triggered by non-apoptotic stimuli as well ${ }^{4-7}$.

The detection of specific coagulation factors, mainly released from the vascular endothelium such as vWF, sTM and ePCR and factors dependent on endothelial activation such as t-PA and PAI-1, could provide information on possible endothelial dysfunction and help differentiate pregnant patients with an altered thrombotic state. The Von Willebrand factor is a high molecular weight glycoprotein and has been proposed as a marker of endothelial dysfunction for many years. It is mainly responsible for platelet adhesion in the subendothelial space and for the initiation of thrombotic events. Thrombomodulin is also a high molecular glycoprotein produced by the endothelial cells. Its role in hemostasis is crucial. It is expressed through the activation and transformation of thrombin from prethrombotic to antithrombotic agent. The endothelial protein $\mathrm{C}$ receptor (EPCR) functions as an important regulator of the protein $\mathrm{C}$ anticoagulant pathway by binding protein $\mathrm{C}$ and enhancing activation through the thrombin-thrombomodulin complex. EPCR binds to both protein $\mathrm{C}$ and activated protein $\mathrm{C}$ (APC) with high affinity. A soluble form of EPCR (sEPCR) circulates in plasma and inhibits APC anticoagulant activity especially during pregnancy ${ }^{8}$. Activation of plasminogen by tissue-type plasminogen activator (t-PA) is enhanced in the presence of fibrin or on the endothelial cell surface. For monitoring these processes, the levels of t-PA and their inhibitor PAI-1 are crucial ${ }^{9,10}$.

\section{MATERIAL AND METHODS}

Healthy pregnant women underwent a complete assessment of endothelial damage. For this purpose, blood was collected into $0.129 \mathrm{M}$ sodium citrate tubes (Vacuette, Greiner) and platelet-poor plasma was prepared within two hours by centrifugation (twice at $3000 \mathrm{x} g$ for $10 \mathrm{~min}$ ). Whole blood and plasma fractions were stored at $-80{ }^{\circ} \mathrm{C}$ until use. All samples were tested by the same laboratory, and one aliquot of each plasma sample was thawed at $37{ }^{\circ} \mathrm{C}$ immediately before the assay. For EMP measurement, $5 \mathrm{ml}$ of blood were collected by venipuncture into
$0.129 \mathrm{M}$ trisodium citrate. Platelet-free plasma was prepared within one hour by two sequential centrifugations at $1000 \mathrm{x} g$ for $10 \mathrm{~min}$.

\section{t-PA and PAI-1}

Tissue-type plasminogen activator antigen and plasminogen activator inhibitor-1 levels were determined by the ELISA method (Technoclone GmbH, Austria).

\section{Von Willebrand factor}

Von Willebrand factor antigen levels were determined by enzyme immunoassay (Instrumentation Laboratory, Italy).

Soluble thrombomodulin antigen and endothelial protein $\mathrm{C}$ receptor levels were determined by the ELISA method (Diagnostica Stago, France).

\section{Endothelial microparticles}

EMPs were quantified in plasma as previously described $^{11}$. Thirty $\mu 1$ of platelet-free plasma were incubated for $30 \mathrm{~min}$ at room temperature, with $10 \mu \mathrm{l}$ of PE-conjugated CD144. The samples were then diluted in $1.0 \mathrm{ml}$ PBS and a known number of fluorescent latex beads (Flowcount, Beckman Coulter Immunotech, France) were added to samples according to the internal standards before flow cytometry analysis. The EMPs were analyzed using Coulter Epics XL (Beckman Coulter, Switzerland, Nyon) as previously described ${ }^{11}$. Using $0.8-\mu \mathrm{m}$ latex beads, EMP were defined as elements less than $1 \mu \mathrm{m}$ in size and positively labeled with PE-conjugated CD144. The results were expressed as the number of EMPs per $1 \mathrm{ml}$ of plasma.

\section{Matrix metalloproteinases}

The MMP-2 and MMP-9 activity in plasma samples was measured by the solid-phase ELISA method ${ }^{12}$ with EDANS/DABCYL FRET peptide (AnaSpec, USA). The results were expressed in reference fluorescence units (RFU). The RFU is a unit of measurement used in ELISA methods employing fluorescence detection. Fluorescence is detected as labeled fragments, conjugated on solid phase, and excited by laser, past a detector. The software interprets the results, calculating the quantity of the fragments from the fluorescence intensity for each sample.

\section{Tissue inhibitor of metalloproreinase-2}

The TIMP-2 activity in plasma samples was measured by solid-phase ELISA (R\&D Systems, USA).

\section{Statistical analysis}

The statistical analysis and graphical presentation were performed using the statistics software (StatSoft CR s. r.o. (2007). STATISTICA Cz). Clinical and laboratory data are reported as means and standard deviation (SD). Differences between trimester were analyzed using the non-parametric Wilcoxon signed-rank test and the non parametric Friedman ANOVA. Other data were analyzed using the Mann-Whitney and Krusal-Walls tests. The level of significance was set at $5 \%$. 


\section{RESULTS}

The levels of vWF antigen continued to increase throughout pregnancy (the mean levels were 1523,2 IU/1, $1733,4 \mathrm{IU} / 1$ and $2162,0 \mathrm{IU} / 1$ in the 1st, 2nd and 3rd trimesters, respectively). In the group, a statistically significant difference in levels was found between the 2 nd and $3 \mathrm{rd}$ trimesters, with the difference between the 1st and 2nd trimesters being on the borderline of statistical significance. At the same time, vWF activity was on the rise (the average levels were $1302 \mathrm{IU} / 1,1500,9 \mathrm{IU} / 1$ and 1819,1 IU/1 in the 1st, 2nd and 3rd trimesters, respectively). A statistically significant difference in levels was found between the 2 nd and 3rd trimesters but not between the 1st and 2nd trimesters.

The levels of thrombomodulin increased significantly during pregnancy (the average levels were $19.05 \mu \mathrm{g} / 1$, $28.47 \mu \mathrm{g} / 1$ and $39.86 \mu \mathrm{g} / 1$ in the $1 \mathrm{st}, 2 \mathrm{nd}$ and 3rd trimesters, respectively). Statistically significant differences in levels were found both between the 2nd and 3rd trimesters and between the 1st and 2nd trimesters.

The levels of soluble EPCR continued to rise throughout pregnancy (the average levels were $201.76 \mu \mathrm{g} / 1$, $274.68 \mu \mathrm{g} / 1$ and $324.07 \mu \mathrm{g} / 1$ in the $1 \mathrm{st}, 2$ nd and 3rd trimesters, respectively). A statistically significant difference in levels was found between the 1st and 2nd trimesters but not between the 2 nd and 3rd trimesters.

The PAI-1 levels increased during the entire pregnancy (the average levels were $36.14 \mu \mathrm{g} / 1,50.07 \mu \mathrm{g} / 1$ and $60.12 \mu \mathrm{g} / 1$ in the $1 \mathrm{st}$, 2nd and 3rd trimesters, respectively). Statistically significant differences in levels were found both between the 2nd and 3rd trimesters and between the 1 st and 2nd trimesters.

The levels of t-PA did not significantly change in the course of pregnancy (the average levels were $2.48 \mu \mathrm{g} / 1$, $2.97 \mu \mathrm{g} / 1$ and $3.34 \mu \mathrm{g} / 1$ in the $1 \mathrm{st}, 2 \mathrm{nd}$ and 3 rd trimesters, respectively). Similarly, no statistically significant differ- ences were found in the levels of MMP-2 (the average levels were 9043.76 RFU [relative fluorescence units], 9315.38 RFU and 8800.27 RFU in the 1st, 2nd and 3rd trimesters, respectively), MMP-9 (the average levels were 8371.90 RFU, 8290.81 RFU and 7470.50 RFU in the 1st, 2nd and 3rd trimesters, respectively), TIMP-2 (the average levels were $92.5 \mu \mathrm{g} / 1,98.5 \mu \mathrm{g} / 1$ and $96.5 \mu \mathrm{g} / 1$ in the 1st, 2nd and 3rd trimesters, respectively) and EMPs (the average counts were $3.83 \times 10^{9}$ particles $/ 1,3.83 \times 10^{9}$ particles $/ 1$ and $3.63 \times 10^{9}$ particles/ 1 in the 1 st, 2 nd and 3 rd trimesters, respectively).

\section{DISCUSSION}

The results show that endothelial activation during pregnancy is different from that in other pathological conditions involving endothelial damage such as acute coronary syndrome or diabetes mellitus ${ }^{13-17}$. These pathological situations are typically characterized by higher levels of both coagulation endothelial markers and MMPs. In these conditions, the mechanism of endothelial damage is probably as follows: enhanced matrix breakdown, attributed primarily to a family of matrix metalloproteinases (MMPs) that are expressed in atherosclerotic plaques by inflammatory cells (macrophages, foam cells) and, to a lesser extent, by SMCs and endothelial cells ${ }^{18}$. This family of enzymes can degrade all components of the extracellular matrix ${ }^{19-24}$.

The activity of MMPs is tightly regulated at the level of gene transcription and is also by their secretion in an inactive zymogen form that requires extracellular activa$\operatorname{tion}^{25-27}$ and co-secretion of the tissue inhibitors of metalloproteinases (TIMPs) $\left(\right.$ ref. ${ }^{28}$ ).

Latent MMPs can be activated by plasmin (produced by the plasminogen activator [uPA] from plasminogen by macrophages), trypsin and chymase (derived from de-

Table 1. Comparison of the levels markers of endothelial activation by trimesters.

\begin{tabular}{|l|c|c|c|c|c|}
\hline $\begin{array}{l}\text { Markers of endo- } \\
\text { thelial activation }\end{array}$ & $\begin{array}{c}\text { I. trimester } \\
\text { average level }\end{array}$ & $\begin{array}{c}\text { II. trimester } \\
\text { average level }\end{array}$ & $\begin{array}{c}\text { III. trimester } \\
\text { average level }\end{array}$ & $\begin{array}{c}\text { P (the com- } \\
\text { parison I. vs II. } \\
\text { trimester) }\end{array}$ & $\begin{array}{c}\text { P (tThe com- } \\
\text { parison II. vs } \\
\text { III. trimester) }\end{array}$ \\
\hline vWf antigen & 1523.2 & 1733.4 & 2162.0 & 0.048 & 0.000 \\
\hline vWf activity & 1302.0 & 1500.9 & 1819.1 & 0.074 & 0.001 \\
\hline Thrombomodulin & 19.05 & 28.47 & 39.86 & 0.000 & 0.000 \\
\hline ePCR & 201.76 & 274.68 & 324.07 & 0.017 & 0.660 \\
\hline PAI - 1 & 36.14 & 50.07 & 60.12 & 0.000 & 0.012 \\
\hline EMP & $3.83 \times 10^{9}$ & $3.83 \times 10^{9}$ & $3.63 \times 10^{9}$ & 0.412 & 1.000 \\
\hline MMP - 2 & 9043.76 & 9315.38 & 8800.27 & 1.000 & 0.972 \\
\hline MMP - 9 & 8371.90 & 8290.81 & 7470.50 & 1.000 & 0.084 \\
\hline TIMP - 2 & 1.85 & 1.97 & 1.93 & 0.506 & 1.000 \\
\hline t-PA & 2.48 & 2.97 & 3.34 & 0.85 & 0.96 \\
\hline
\end{tabular}


granulating mast cells $\left.{ }^{29-33}\right)$. Increased MMP production can be induced by oxidized lipids, reactive oxygen species, CD-40 ligation, inflammatory cytokines, tenascin-C derived from macrophages, and hemodynamic stress ${ }^{34-38}$.

The situation during pregnancy is different ${ }^{39}$. Changes in extracellular matrix composition and matrix metalloproteinase activity also promote vascular remodeling but only in the uterus. Assessment of the predisposing risk factors, the biologically active factors, and the vascular mediators associated with vascular remodeling must be made from the concentration of risk factors in the whole blood circulation, regulation mechanisms of molecules and other interactions.

From this viewpoint, it is not possible to fully clarify the pathophysiology of endothelial dysfunction during pregnancy. The levels of MMPs are not increased in the circulation and the local situation in the uterus cannot be monitored this way.

While the amounts of newly synthesized MMPs are regulated mainly at the levels of transcription, the proteolytic activities of existing MMPs are controlled through the activation of proenzymes and the inhibition of active enzymes by endogenous inhibitors such as $\beta 2$ macroglobulin and TIMPs locally in the uterus ${ }^{40}$. TIMP-1 through TIMP-4 inhibit active MMP-2 through tight but non-covalent binding of their N-terminal domains to the catalytic domain of MMP-2 in a 1:1 stoichiometry ${ }^{41-43}$. In addition, TIMP-2 and TIMP-3 can tether pro-MMP-2 into cell surface ternary complexes with MT-MMPs .

Together with MMP-9 (gelatinase B), MMP-2 degrades gelatin (denatured collagen) and type IV collagen, the major component of basement membranes ${ }^{44}$. It can also degrade the following matrix proteins: collagens V, VII, and $\mathrm{X}$, decorin, elastin and fibronectin ${ }^{45-47}$.

MMP-2 processes and modulates the functions of many other vasoactive and pro-inflammatory molecules including adrenomedullin, big endothelin-1, calcitonin gene-related peptide, CCL7/MCP-3, CXCL12/SDF-1, galectin-3, IGFBP-3, IL-1 $\beta$, S100A8, and S100A9. These molecules represent new potential molecular markers of endothelial damage during pregnancy.

\section{ACKNOWLEDGEMENTS}

Supported by the Czech Ministry of Health grant projects IGA NR 9282-3(2007) and NS 10319-3/2009 86-14, the grant project UP LF-2011-006 and by the project MSM 6198959205 of the MSMT Czech Republic.

\section{REFERENCES}

1. Machac S, Lubusky M, Prochazka M, Streda R. Prevalence of inherited thrombophilia in patients with severe ovarian hyperstimulation syndrome. Biomed Pap Med Fac Univ Palacky Olomouc Czech Repub 2006;150(2):289-92.

2. Prochazka M, Lubusky M, Slavik L, Hrachovec P, Zielina P, Kudela M, Lindqvist PG. Selected pregnancy variables in women with placental abruption. Biomed Pap Med Fac Univ Palacky Olomouc Czech Repub 2006;150(2):271-3.
3. Combes V, Simon AC, Grau GE, Arnoux D, Camoin L, Sabatier F, Mutin M, Sanmarco M, Sampol J, Dignat-George F. In vitro generation of endothelial microparticles and possible prothrombotic activity in patients with lupus anticoagulant. J Clin Invest 1999;104(1):93-102.

4. Leroyer AS, Tedgui A, Boulanger CM. Role of microparticles in atherothrombosis. J Intern Med 2008;263(5):528-37.

5. Bulava A, Slavík L, Fiala M, Heinc P, Skvarilova M, Lukl J, Krcová V, Indrák K. Endothelial damage and activation of the hemostatic system during radiofrequency catheter isolation of pulmonary veins. J Interv Card Electrophysiol 2004;10(3):271-9.

6. Boulanger CM, Amabile N, Tedgui A. Circulating microparticles: a potential prognostic marker for atherosclerotic vascular disease. Hypertension 2006;48(2):180-6.

7. Canault M, Leroyer AS, Peiretti F, Lesèche G, Tedgui A, Bonardo B, Alessi MC, Boulanger CM, Nalbone G. Microparticles of human atherosclerotic plaques enhance the shedding of the tumor necrosis factor-alpha converting enzyme/ADAM17 substrates, tumor necrosis factor and tumor necrosis factor receptor-1. Am J Pathol 2007; 171(5):1713-23.

8. Slavik L, Krcova V, Hlusi A, Prochazkova J, Prochazka M, Ulehlova J, Indrak K. Molecular pathophysiology of thrombotic states and their impact to laboratory diagnostics. Biomed Pap Med Fac Univ Palacky Olomouc Czech Repub 2009;153(1):19-25.

9. Juhan-Vague I, Alessi MC, Mavri A, Morange PE. Plasminogen activator inhibitor-1, inflammation, obesity, insulin resistance and vascular risk. J Thromb Haemost 2003;1(7):1575-9.

10. Doggen CJ, Bertina RM, Cats VM, Reitsma PH, Rosendaal FR. The $4 \mathrm{G} / 5 \mathrm{G}$ polymorphism in the plasminogen activator inhibitor-1 gene is not associated with myocardial infarction. Thromb Haemost 1999;82(1):115-20.

11. Vidal C, Spaulding C, Picard F, Schaison F, Melle J, Weber S, Fontenay-Roupie M. Flow cytometry detection of platelet procoagulation activity and microparticles in patients with unstable angina treated by percutaneous coronary angioplasty and stent implantation. Thromb Haemost 2001;86(3):784-90.

12. Beekman B, Drijfhout JW, Bloemhoff W, Ronday HK, Tak PP, te Koppele JM. Convenient fluorometric assay for matrix metalloproteinase activity and its application in biological media. FEBS Lett 1996;390(2):221-5.

13. Essayagh S, Xuereb JM, Terrisse AD, Tellier-Cirioni L, Pipy B, Sie P. Microparticles from apoptotic monocytes induce transient platelet recruitment and tissue factor expression by cultured human vascular endothelial cells via a redoxsensitive mechanism. Thromb Haemost 2007;98:831-7.

14. Satta N, Freyssinet JM, Toti F. The significance of human monocyte thrombomodulin during membrane vesiculation and after stimulation by lipopolysaccharide. Br J Haematol 1997;96:534-42.

15. Sabatier F, Roux V, Anfosso F, Camoin L, Sampol J, Dignat-George F. Interaction of endothelial microparticles with monocytic cells in vitro induces tissue factor-dependent procoagulant activity. Blood 2002;99:3962-70.

16. Perez-Casal M, Downey C, Fukudome K, Marx G, Toh CH. Activated protein $\mathrm{C}$ induces the release of microparticle-associated endothelial protein C receptor. Blood 2005;105:1515-22.

17. Bouzeghrane F, Zhang X, Gevry G, Raymond J. Deep vein thrombosis resolution is impaired in diet-induced type 2 diabetic mice. $\mathrm{J}$ Vasc Surg 2008;48(6):1575-84.

18. Galis ZS, Sukhova GK, Lark MW, Libby P. Increased expression of matrix metalloproteinases and matrix degrading activity in vulnerable regions of human atherosclerotic plaques. J Clin Invest 1994;94:2493-503.

19. Brown DL, Hibbs MS, Kearney M, Loushin C, Isner JM. Identification of $92-\mathrm{kD}$ gelatinase in human coronary atherosclerotic lesions. Association of active enzyme synthesis with unstable angina. Circulation 1995;91:2125-31.

20. Nikkari ST, O'Brien KD, Ferguson M, Hatsukami T, Welgus HG, Alpers CE, Clowes AW. Interstitial collagenase (MMP-1) expression in human carotid atherosclerosis. Circulation 1995;92:1393-8.

21. Li Z, Li L , Zielke HR, Cheng L, Xiao R, Crow MT , StetlerStevenson WG, Froehlich J , Lakatta EG. Increased expression of 
72-kd type IV collagenase (MMP-2) in human aortic atherosclerotic lesions. Am J Pathol 1996;148:121-8.

22. Galis ZS, Sukhova GK, Libby P. Microscopic localization of active proteases by in situ zymography: detection of matrix metalloproteinase activity in vascular tissue. FASEB J 1995;9:974-80.

23. Xu XP, Meisel SR, Ong JM, Kaul S, Cercek B, Rajavashisth TB, Sharifi B, Shah PK. Oxidized low-density lipoprotein regulates matrix etalloproteinase-9 and its tissue inhibitor in human monocytederived macrophages. Circulation 1999;99:993-8.

24. Rajavashisth TB, Xu XP, Jovinge S, Meisel S, Xu XO, Chai NN, Fishbein MC, Kaul S, Cercek B, Sharifi B, Shah PK. Membrane type 1 matrix metalloproteinase expression in human atherosclerotic plaques: evidence for activation by proinflammatory mediators. Circulation 1999;99:3103-9.

25. Rajavashisth TB, Liao JK, Galis ZS, Tripathi S, Laufs U, Tripathi J, Chai NN, Xu XP, Jovinge S, Shah PK, Libby P. Inflammatory cytokines and oxidized low density lipoproteins increase endothelial cell expression of membrane type 1-matrix metalloproteinase. J Biol Chem 1999;274:11924-9.

26. Herman MP, Sukhova GK, Libby P, Gerdes N, Tang N, Horton DB, Kilbride M, Breitbart RE, Chun M, Schönbeck U. Expression of neutrophil collagenase (matrix metalloproteinase-8) in human atheroma: a novel collagenolytic pathway suggested by transcriptional profiling. Circulation 2001;104:1899-904.

27. Shah PK, Falk E, Badimon JJ, Fernandez-Ortiz A, Mailhac A, Villareal-Levy G, Fallon JT, Regnstrom J, Fuster V. Human monocyte-derived macrophages induce collagen breakdown in fibrous caps of atherosclerotic plaques. Potential role of matrix-degrading metalloproteinases and implications for plaque rupture. Circulation 1995;92:1565-9.

28. Shah PK. Role of inflammation and metalloproteinases in plaque disruption and thrombosis. Vasc Med 1998;3:199-206.

29. Sukhova GK, Schönbeck U, Rabkin E, Schoen FJ, Poole AR, Billinghurst RC, Libby P. Evidence for increased collagenolysis by interstitial collagenases- 1 and -3 in vulnerable human atheromatous plaques. Circulation 1999;99:2503-9.

30. Lee RT, Schoen FJ, Loree HM, Lark MW, Libby P. Circumferential stress and matrix metalloproteinase 1 in human coronary atherosclerosis. Implications for plaque rupture. Arterioscler Thromb Vasc Biol 1996;16:1070-3.

31. Galis ZS, Muszynski M, Sukhova GK, Simon-Morrissey E, Libby P. Enhanced expression of vascular matrix metalloproteinases induced in vitro by cytokines and in regions of human atherosclerotic lesions. Ann NY Acad Sci 1995;748:501-7.

32. Galis ZS, Sukhova GK, Kranzhofer R, Clark S, Libby P. Macrophage foam cells from experimental atheroma constitutively produce matrix-degrading proteinases. Proc Natl Acad Sci USA 1995;92:402-6.

33. Kol A, Sukhova GK, Lichtman AH, Libby P. Chlamydial heat shock protein 60 localizes in human atheroma and regulates macrophage tumor necrosis factor-alpha and matrix metalloproteinase expression. Circulation 1998;98:300-7.
34. Mach F, Schönbeck U, Fabunmi RP, Murphy C, Atkinson E, Bonnefoy JY, Graber P, Libby P. T lymphocytes induce endothelial cell matrix metalloproteinase expression by a CD40Ldependent mechanism: implications for tubule formation. Am J Pathol 1999;154:229-38.

35. Schönbeck U, Mach F, Sukhova GK, Murphy C, Bonnefoy JY, Fabunmi RP, Libby P. Regulation of matrix metalloproteinase expression in human vascular smooth muscle cells by T lymphocytes: a role for CD40 signaling in plaque rupture? Circ Res 1997;81:44854.

36. Wallner K, Li C, Shah PK, Fishbein MC, Forrester JS, Kaul S, Sharifi BG. Tenascin-C is expressed in macrophage-rich human coronary atherosclerotic plaque. Circulation 1999;99:1284-9.

37. Sukhova GK, Shi GP, Simon DI, Chapman HA, Libby P. Expression of the elastolytic cathepsins $\mathrm{S}$ and $\mathrm{K}$ in human atheroma and regulation of their production in smooth muscle cells. $\mathrm{J}$ Clin Invest 1998;102:576-83.

38. Shi GP, Sukhova GK, Grubb A, Ducharme A, Rhode LH, Lee RT, Ridker PM, Libby P, Chapman HA. Cystatin C deficiency in human atherosclerosis and aortic aneurysms. J Clin Invest 1999;104:1191-7.

39. Sheppard SJ, Khalil RA. Risk factors and mediators of the vascular dysfunction associated with hypertension in pregnancy. Cardiovasc Hematol Disord Drug Targets 2010;10(1):33-1.

40. Tamura T, Nakanishi T, Kimura Y, Hattori T, Sasaki K, Norimatsu H, Takahashi K, Takigawa M. Nitric oxide mediates interleukin1-induced matrix degradation and basic fibroblast growth factor release in cultured rabbit articular chondrocytes: a possible mechanism of pathological neovascularization in arthritis. Endocrinology 1996;137:3729.

41. Nagase H, Woessner JF Jr. Matrix metalloproteinases. J. Biol. Chem 1999;274:21491.

42. Morgunova E, Tuuttila A, Bergmann U, Isupov M, Lindqvist Y, Schneider G, Tryggvason K. Structure of human pro-matrix metalloproteinase-2: activation mechanism revealed. Science 1999;284:1667.

43. Fang J, Shing Y, Wiederschain D, Yan L, Butterfield C, Jackson G, Harper J, Tamvakopoulos G, Moses MA. Matrix metalloproteinase- 2 is required for the switch to the angiogenic phenotype in a tumor model. Proc Natl Acad Sci USA 2000;97:3884.

44. Moses MA, Wiederschain D, Loughlin KR, Zurakowski D, Lamb CC, Freeman MR. Increased incidence of matrix metalloproteinases in urine of cancer patients. Cancer Res 1998;58:1395.

45. Matrisian, L.M. The matrix-degrading metalloproteinases. BioEssays 1992;14:455.

46. Ogata Y, Enghild JJ, Nagase H. Matrix metalloproteinase 3 (stromelysin) activates the precursor for the human matrix metalloproteinase 9. J Biol Chem 1992;267:3581.

47. Sires UI, Griffin GL, Broekelmann TJ, Mecham RP, Murphy G, Chung AE, Welgus HG, Senior RM. Degradation of entactin by matrix metalloproteinases. Susceptibility to matrilysin and identification of cleavage sites. J Biol Chem 1993;268:2069. 
